\title{
Therapeutic evaluation of interleukin 1-beta antagonist Anakinra against traumatic brain injury in rats
}

\author{
Askin Esen Hasturk, M.D., ${ }^{1}$ Erdal Resit Yilmaz, M.D., ${ }^{2}$ Erhan Turkoglu, M.D., ${ }^{2}$ Hayri Kertmen, M.D., ${ }^{2}$ \\ Bahriye Horasanli, M.D., ${ }^{3}$ Nazli Hayirli, MSc., ${ }^{4}$ Imge Berrin Erguder, M.D., ${ }^{5}$ Oya Evirgen, M.D. ${ }^{4}$
}

\author{
1'Department of Neurosurgery, Oncology Training and Research Hospital, Ankara; \\ 2Department of Neurosurgery, Diskapi Yildirim Beyazit Training and Research Hospital, Ankara; \\ ${ }^{3}$ Department of Neurology, Baskent University Faculty of Medicine, Ankara; \\ ${ }^{4}$ Department of Histology and Embryology, Ankara University Faculty of Medicine, Ankara; \\ ${ }^{5}$ Department of Biochemistry, Ankara University Faculty of Medicine, Ankara
}

\begin{abstract}
BACKGROUND: The aim of this study was to evaluate the therapeutic efficiency of Anakinra, an IL-I $\beta$ antagonist with anti-inflammatory effects, in an experimental model of traumatic brain injury (TBI).

METHODS: Fifty-four rats underwent TBI after a weighted object was dropped onto a metal disc secured to their skulls. Animals were randomized into 3 main groups: control $(n=18), T B I+$ saline $(n=\mid 8$; six animals per time-point) with samples obtained at the first, sixth and twenty-fourth $h$ postoperatively, and $T B I+$ Anakinra $(n=I 8$; six animals per time-point) with brain samples obtained at the first, sixth and twenty-fourth h postoperatively. Brain tissue and blood serum were extracted for the analysis of IL-I $\beta$, malondialdehyde, glutathione peroxidase, superoxide dismutase, and catalase levels. Tissue sections were evaluated histopathologically under a light microscope.
\end{abstract}

RESULTS: After trauma, tissue and serum IL- I $\beta$ levels were significantly elevated and after Anakinra administration, these levels substantially decreased. Glutathione peroxidase, superoxide dismutase, and catalase activity decreased following TBI and Anakinra administration proved effective in increasing the activity of these antioxidant enzymes. Histopathological analysis confirmed that Anakinra might protect the brain tissue and nerve cells from injury.

CONCLUSION: Results demonstrate that Anakinra reduces the development of inflammation and tissue injury events associated with TBI.

Key words: Antioxidant; anakinra; interleukin-I; neuroprotection; traumatic brain injury.

\section{INTRODUCTION}

Traumatic brain injury (TBI) immediately causes direct mechanical damage to the brain, referred to as the primary damage, ${ }^{[1]}$ resulting in the immediate death of a number of neurons that cannot be recovered or regenerated. However, neurons continue to die for hours after TBI, representing a

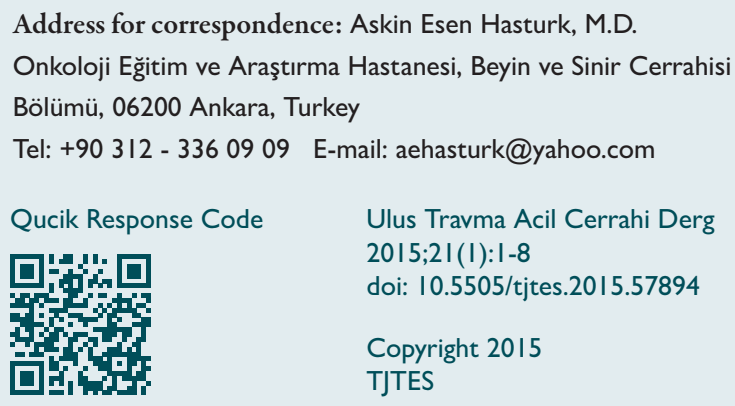

potentially avoidable event. This secondary neuronal death is determined by a large number of cellular, molecular, and biochemical cascades. One such cascade thought to contribute to the evolution of this secondary damage is the local inflammatory response in the injured brain tissue. ${ }^{[2]}$ Microglial cells have been suggested to be the source of cytotoxic cytokines, such as tumor necrosis factor alpha (TNF- $\alpha$ ) and interleukin I $\beta$ (IL-I $\beta$ ), killing oligodendrocytes. In fact, increased synthesis and/or secretion of IL-I $\beta$ is detectable at the injury site within one $\mathrm{h}$ after spinal cord injury (SCI). IL-I $\beta$ is a member of the interleukin I cytokine family. The gene encoding IL-I $\beta$, along with eight other IL-I family genes, form a cytokine cluster on chromosome $2 .^{[3]} \mathrm{IL}-\mathrm{I} \beta$ is produced by activated macrophages as a pro-protein, which is proteolytically processed to its active form by caspase I (CASPI/ICE). This cytokine is an important mediator of the inflammatory response and involves in a variety of cellular activities, including cell proliferation, differentiation, and apoptosis. ${ }^{[3]}$ 
IL-I is produced in response to inflammatory stimuli and mediates various physiologic responses, including inflammatory and immunologic reactions. Anakinra, an antagonist expressed in many tissues and organs, has been shown to competitively inhibit the binding of IL-I to the IL-I type receptor. [4] In patients with rheumatoid arthritis, this natural IL-I receptor antagonist is not found in effective concentrations to counteract elevated IL-I concentrations. Thus, Kineret is not considered a disease-modifying anti-rheumatic drug, but rather a biological response modifier due to its ability to selectively target the pathologic element of the disease. ${ }^{[5]}$

In the current study, the following endpoints of the inflammatory response were determined: histological damage; cytokine expression (IL-I $\beta$ ); measurement of lipid peroxidation and oxidative stress (glutathione peroxidase, malondialdehyde, and superoxide dismutase) and these various factors were used to evaluate whether Anakinra administration could protect brain tissue following traumatic brain injury.

\section{MATERIALS AND METHODS}

Fifty-four adult male Wistar albino rats weighing 300-350 g were used in this study. Animal care and all experiments were in accordance with the European Communities Council Directive of November 24, 1986 (86/609/EEC) on the protection of animals for experimental use. All experimental procedures used in this research were approved by the ethical committee of the Ministry of Health, Ankara Education and Research Hospital.

\section{Surgical Procedure and Sample Preparation}

All rats were kept under environmentally controlled conditions at $22-25^{\circ} \mathrm{C}$ with appropriate humidity, a I2-h light cycle, and free access to food and water. The surgical procedure was performed under general anesthesia induced by intraperitoneal (IP) xylazine (10 mg/kg; Bayer, Istanbul, Turkey) and Ketamine hydrochloride $(50 \mathrm{mg} / \mathrm{kg}$; Parke-Davis, Istanbul, Turkey). A rectal probe was inserted and the animals were positioned on a heating pad in order to ensure that their body temperature was maintained at $37^{\circ} \mathrm{C}$. A moderate brain-injury model, described by Marmarou et al. and modified by Ucar et al., was applied for head trauma. ${ }^{[6,7]}$ Briefly, rats were placed in prone position and a midline incision was made on the head to expose the coronal and lambdoid sutures. A metallic disc in $10 \mathrm{~mm}$ diameter and $3 \mathrm{~mm}$ thickness was fixed to the cranium using bone wax, and a lead object weighing $450 \mathrm{~g}$ was allowed a free fall from a height of $70 \mathrm{~cm}$ through a copper tube onto the metal disc. The head of the animals was supported on a $10-\mathrm{cm}$ foam bed providing confirmation of impact. After surgery, I.0 cc of saline was subcutaneously administered to replace the blood volume lost during surgery and the wound was closed in layers with silk sutures. All animals were anesthetized with the above-mentioned agents at $24 \mathrm{~h}$ after trauma and their brains were extracted without any damage. Neural tissue samples were obtained by excising the left frontoparietal lobes from the boundary of the interhemispheric fissure and were subjected to biochemical analyses. The remaining parts of the brains were maintained in formaldehyde solution for histopathological analysis.

\section{Experimental Groups}

Rats were randomly allocated into the following 3 main groups and subgroups: Control: ( $n=18,6$ rats per time window); rats underwent skin incisions only and non-traumatic brain samples were obtained at the first, sixth and twenty-fourth $h$ after surgery.

$T B I+$ Saline: $(n=18,6$ rats per time window); rats were subjected to TBI and received a single IP dose of $\mathrm{I} \mathrm{mL} / \mathrm{kg}$ saline. Traumatic brain tissue samples were obtained at the first, sixth and twenty-fourth $h$ after surgery.

TBI + Anakinra: ( $n=18,6$ rats per time window); rats were subjected to $\mathrm{TBI}$ and received a single IP dose of Kineret (Anakinra, Swedish Orphan Biovitrum AB, Stockholm, Sweden) immediately following TBI. Traumatic brain tissue samples were then obtained at the first, sixth and twenty-fourth $h$ after surgery.

\section{Cytokine Assay}

Serum and tissue IL-I $\beta$ concentrations were determined using the double-antibody sandwich enzyme-linked immunosorbent assay ( $R$ \& D systems, Minneapolis, MN, USA) according to the manufacturer's instructions.

\section{Measurement of Lipid Peroxidation and Oxidative Stress \\ Glutathione Peroxidase Analysis}

Glutathione peroxidase (GSH-Px) activity was measured following changes in NADPH absorbance at $340 \mathrm{~nm} \cdot{ }^{[8]}$ In the activity calculations (IU, international unit), extinction coefficients of NADPH were used for GSH-Px. Results were expressed as IU/mg protein.

\section{Malondialdehyde Analysis}

Malondialdehyde (MDA) is formed from the breakdown of polyunsaturated fatty acids and serves as an important and reliable index for determining the extent of peroxidation reactions. ${ }^{[9]}$ Tissue MDA levels were determined by a method based on a reaction with thiobarbituric acid (TBA). Briefly, samples were mixed with two volumes of cold saline solution containing $0.001 \%$ butylated hydroxytoluene (BHT) $(200$ $\mu \mathrm{l}$ of $0.01 \% \mathrm{BHT}$ solution in methanol) and $0.07 \%$ sodium dodecyl sulfate (SDS) $(20 \mu \mathrm{l}$ of $7 \%$ SDS). One $\mathrm{ml}$ of sample was then added to $500 \mu \mathrm{l}$ of $0.0 \mathrm{I} \mathrm{NH} 2 \mathrm{SO} 4$ and $500 \mu \mathrm{l}$ of the TBA reagent $(0.67 \%$ TBA in $50 \%$ acetic acid) to precipitate protein. Samples were heated in boiling water for $60 \mathrm{~min}$, and after cooling, an equal volume $(2 \mathrm{ml})$ of $\mathrm{n}$-butanol was added 
to each test tube and mixed. The mixture was centrifuged at 4,000 rpm for $10 \mathrm{~min}$ at room temperature. The absorbance of the organic layer in a I-ml cell was read at $535 \mathrm{~nm}$ (Molecular Devices Corporation, Sunnyvale, CA, USA). MDA concentrations were expressed as nanomoles per milligram wet tissue weight.

\section{Superoxide Dismutase Analysis}

Total superoxide dismutase (SOD) ( $\mathrm{Cu}-\mathrm{Zn}$ and $\mathrm{Mn}$, EC I.I5.I.I) activity was determined according to the method of Sun et al. ${ }^{\left[{ }^{10]}\right.}$ The principle of the method is based on the inhibition of nitroblue tetrazolium (NBT) reduction by the xanthine-xanthine oxidase system as a superoxide generator. Activity was assessed in the ethanol phase of the supernatant after $1.0 \mathrm{ml}$ ethanol/chloroform mixture $(5 / 3, \mathrm{v} / \mathrm{v})$ was added to the same volume of sample and centrifuged. One unit of SOD was defined as the enzyme amount causing $50 \%$ inhibition in the NBT reduction rate. SOD activity was expressed as $\mathrm{U} / \mathrm{mg}$ protein.

\section{Catalase Analysis}

Catalase (CAT) activity was determined by the method described by Aebi. ${ }^{\left[{ }^{\prime \prime}\right]}$ The principle of CAT activity is based on the determination of the rate constant $(k, s e c-l)$ or of the hydrogen peroxide decomposition rate at $240 \mathrm{~nm}$. Results were expressed as $\mathrm{kU} / \mathrm{g}$ of protein.

\section{Histopathological Procedures}

For histological examination, brain tissue samples were fixed at 10\% neutral buffered formalin, dehydrated through a graded series of ethanol and embedded in paraffin. $5 \mu \mathrm{m}$ thick sections stained with hematoxylin-eosin were analyzed and photographed with light microscopy (Olympus CX2I, Olympus America Inc., Melville, NY, USA). In all groups, a semi quantitative scoring system, ranging between 0 and 3 , was used for grading both histopathological changes (vascular congestion, PMNL infiltration, gliosis/satellitosis and spongiosis) and neuronal degeneration signs (cytoplasmic eosinophilia and nuclear pyknosis) in the brain tissues of each animal. Histopathological changes were evaluated by two observers blinded to the groups and scored as follows: 0: absent; I: mild; 2: moderate; 3: common. Histopathological scores for each group was calculated averaging the scores of each animal in groups. ${ }^{[12]}$

\section{Statistical Analysis}

Data were analyzed using the Statistical Package for Social Sciences (SPSS) software version 19.0 for Windows (SPSS Inc., Chicago, IL). Non-parametric tests were applied and the Mann-Whitney $U$ test was used to compare two independent groups while the Kruskal-Wallis test was used to compare more than two groups. The Wilcoxon Signed Ranks Test was used to compare two dependent groups while the Friedman Test was used to compare more than two groups. Bonferroni correction for multiple tests was used for post-hoc comparisons. All differences associated with a chance probability of 0.05 or less were considered statistically significant. Continuous variables were presented as mean $\pm S D$.

\section{RESULTS}

\section{Tissue and Serum IL-1 $\beta$ Analysis}

Table I summarizes the changes in tissue and serum levels of IL-I $\beta$. Mean tissue and serum level of IL-I $\beta$ were the same although tissue and serum samples were obtained at different time periods. There were statistically significant differences between the trauma (I77.24 $\pm 6.24 \mathrm{pg} / \mathrm{ml})$, con-

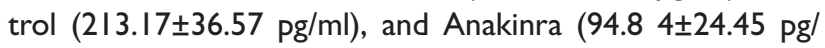
$\mathrm{ml}$ ) groups at the first $\mathrm{h}$ after trauma with regard to mean tissue IL-I $\beta$ activity $(p=0.00 I)$. After the sixth $h$, increased tissue IL-I $\beta$ activity in trauma- and Anakinra-treated groups was shown at $180.86 \pm 5.89 \mathrm{pg} / \mathrm{ml}$ and $137.90 \pm 65.02 \mathrm{pg} / \mathrm{ml}$, respectively. There was also a statistically significant difference determined between the groups $(p=0.00 \mathrm{I})$. Trauma (214.78 $\pm 45.06 \mathrm{pg} / \mathrm{ml})$, control $(2 / 3.17 \pm 36.57 \mathrm{pg} / \mathrm{ml})$, and Anakinra $(201.42 \pm 39.32 \mathrm{pg} / \mathrm{ml})$ groups were compared at the twenty-fourth $h$ after trauma with regard to mean tissue IL-I $\beta$ activity and no statistically significant difference was found $(p=0.149)$, even though tissue levels of $I L-I \beta$ in Anakinra-treated groups continued to decline. There were,

Table I. Summarizing IL-I $\beta$ changes in the tissue and serum

\begin{tabular}{|c|c|c|c|c|}
\hline Variables (tissue) & Control group & Trauma group & Anakinra group & $\mathbf{p}$ \\
\hline I h IL-I $\beta$ (pg/ml) & $213.17 \pm 36.57$ & $177.24 \pm 6.26$ & $94.84 \pm 24.45$ & 0.001 \\
\hline $6 \mathrm{~h} \mathrm{IL-I \beta |}$ & & $80.86 \pm 5.39$ & $137.90 \pm 65.02$ & 0.001 \\
\hline $24 \mathrm{~h} \mathrm{IL-I} \beta$ & & $214.78 \pm 45.06$ & $201.42 \pm 39.32$ & 0.149 \\
\hline Variables (serum) & Control group & Trauma group & Anakinra group & $\mathbf{p}$ \\
\hline I h IL-I $\beta$ (pg/ml) & $57.42 \pm 4.14$ & $50.14 \pm 10.65$ & $70.91 \pm 1.90$ & 0.005 \\
\hline $6 \mathrm{~h} \mathrm{IL-I} \beta$ & & $37.51 \pm 4.12$ & $154.56 \pm 55.70$ & 0.001 \\
\hline
\end{tabular}


however, statistically significant differences between trauma $(50.15 \pm 4.88 \mathrm{pg} / \mathrm{ml})$, control $(60.05 \pm 2.19 \mathrm{pg} / \mathrm{ml})$ and Anakinratreated $(52.25 \pm 2.0 \mathrm{l} \mathrm{pg} / \mathrm{ml})$ groups one $\mathrm{h}$ after trauma with regard to mean serum IL-I $\beta$ activity $(p=0.003)$. Additionally, six $h$ after trauma, a statistically significant increase $(p=0.00 \mathrm{I})$ in serum IL-I $\beta$ activity was observed in the Anakinra-treated group (I54.56 $\pm 55.70 \mathrm{pg} / \mathrm{ml})$.

\section{Tissue and Serum MDA Analysis}

Mean tissue MDA levels in the trauma group were 7.16 1.02 $\mathrm{nmol} / \mathrm{mg}$, I I.66 $\pm 2.94 \mathrm{nmol} / \mathrm{mg}$, and $15.95 \pm 02.98 \mathrm{nmol} / \mathrm{mg}$ at the first, sixth and twenty-fourth $h$, respectively. Mean tissue levels in the Anakinra group were $7.20 \pm 4.39 \mathrm{nmol} / \mathrm{mg}$, I I $.46 \pm 4.00 \mathrm{nmol} / \mathrm{mg}$, and $9.37 \pm 4.44 \mathrm{nmol} / \mathrm{mg}$ at the first, sixth and twenty-fourth $\mathrm{h}$ after trauma, respectively. A statistically significant difference was observed when mean serum MDA levels in trauma and Anakinra groups were compared with the control group $(10.25 \pm 2.12 \mathrm{nmol} / \mathrm{mg})$ at all time points $(p=0.008)$. Mean serum MDA levels in the trauma groups were $0.10 \pm 0.04 \mathrm{nmol} / \mathrm{mg}$ and $0.07 \pm 0.04 \mathrm{nmol} / \mathrm{mg}$ at the first and sixth h, respectively. Mean tissue levels in the Anakinra group were $0.04 \pm 0.01 \mathrm{nmol} / \mathrm{mg}$ and $0.05 \pm 0.01 \mathrm{nmol} / \mathrm{mg}$ at the fist and sixth $\mathrm{h}$ after trauma, respectively. A statistically significant difference was seen when mean serum MDA levels in trauma and Anakinra groups were compared with the control group $(0.04 \pm 0.0 \mathrm{I} \mathrm{nmol} / \mathrm{mg})$ at all time-points $(p=0.005)$ (Table 2).

\section{Tissue and Serum GPx Analysis}

Mean tissue GPx levels at the first $h$ following trauma for trauma $(0.28 \pm 0.12 \mathrm{lU} / \mathrm{mg})$, control $(0.27 \pm 0.1 \mathrm{I} \mathrm{IU} / \mathrm{mg})$, and Anakinra groups $(0.21 \pm 0.25 \mathrm{lU} / \mathrm{mg})$ were not significantly different $(p=0.899)$. Six hours following TBI, mean tissue GPX levels were $0.25 \pm 0.12 \mathrm{lU} / \mathrm{mg}$ in the trauma groups, $0.4 \mathrm{I} \pm 0.33$ $\mathrm{IU} / \mathrm{mg}$ in the Anakinra groups, and $0.27 \pm 0.1 \mathrm{I} \mathrm{IU} / \mathrm{mg}$ in the control group; there were no statistically significant differences between groups at this time-point $(p=0.05)$. After twentyfour $h$, mean tissue GPx continued to decline in the Anakinratreated group $(0.3 \mathrm{I} \pm 0.19 \mathrm{IU} / \mathrm{mg})$, but this reduction was not determined to be statistically significant $(p=0.189)$. Mean serum GPx levels in trauma groups were $0.0041 \pm 0.0007 \mathrm{IU} / \mathrm{mg}$ and $0.0033 \pm 0.002 \mathrm{IU} / \mathrm{mg}$ at the first and sixth $\mathrm{h}$, respectively. The mean serum GPx levels in the Anakinra group were $0.0029 \pm 0.00 \mathrm{II} \mathrm{IU} / \mathrm{mg}$ and $0.00 \mathrm{I} \pm 0.00 \mathrm{IU} / \mathrm{mg}$ at the first and

Table 2. Biochemical alterations in the tissue and serum among groups

\begin{tabular}{|c|c|c|c|c|}
\hline Variables (tissue) & Control & Trauma & Anakinra & $\mathbf{p}$ \\
\hline I h MDA (nmol/mg) & $10.25 \pm 2.12$ & $7.16 \pm 1.02$ & $7.20 \pm 4.39$ & 0.008 \\
\hline $6 \mathrm{~h} \mathrm{MDA}$ & $10.25 \pm 2.12$ & $11.66 \pm 2.95$ & $11.46 \pm 4.00$ & 0.567 \\
\hline $24 \mathrm{~h}$ MDA & $10.25 \pm 2.12$ & $15.95 \pm 2.98$ & $9.37 \pm 4.44$ & 0.008 \\
\hline I h GPx (IU/mg) & $0.27 \pm 0.11$ & $0.28 \pm 0.12$ & $0.21 \pm 0.25$ & 0.899 \\
\hline $6 \mathrm{~h} \mathrm{GPx}$ & $0.27 \pm 0.11$ & $0.25 \pm 0.12$ & $0.4 I \pm 0.33$ & 0.049 \\
\hline 24 h GPx & $0.27 \pm 0.11$ & $0.39 \pm 0.13$ & $0.31 \pm 0.14$ & 0.189 \\
\hline I h SOD (U/mg) & $|4.5| \pm \mid .74$ & $10.05 \pm 0.52$ & $7.63 \pm 1.84$ & 0.001 \\
\hline $6 \mathrm{~h} \mathrm{SOD}$ & $|4.5| \pm \mid .74$ & $|7.82 \pm 1.2|$ & $10.14 \pm 4.00$ & 0.003 \\
\hline 24 h SOD & $|4.5| \pm 1.74$ & $19.92 \pm 4.25$ & $13.46 \pm 1.46$ & 0.144 \\
\hline I h CAT (IU/mg) & $3.48 \pm 0.91$ & $4.67 \pm 1.69$ & $10.63 \pm 3.55$ & 0.001 \\
\hline $6 \mathrm{~h}$ CAT & $3.48 \pm 0.91$ & $4.06 \pm 0.47$ & $4.83 \pm 1.07$ & 0.007 \\
\hline $24 \mathrm{~h}$ CAT & $3.48 \pm 0.91$ & $7.11 \pm 1.85$ & $1.95 \pm 0.11$ & 0.004 \\
\hline Variables (serum) & Control & Trauma & Anakinra & $\mathbf{p}$ \\
\hline I h MDA (nmol/mg) & $0.04 \pm 0.01$ & $0.10 \pm 0.04$ & $0.04 \pm 0.01$ & 0.004 \\
\hline $6 \mathrm{~h}$ MDA & $0.04 \pm 0.01$ & $0.07 \pm 0.04$ & $0.05 \pm 0.01$ & 0.005 \\
\hline I h GPx (IU/mg) & $0.003 \pm 0.001$ & $0.004 \pm 0.007$ & $0.002 \pm 0.001$ & 0.061 \\
\hline 6 h GPx & $0.003 \pm 0.001$ & $0.005 \pm 0.002$ & $0.002 \pm 0.001$ & 0.003 \\
\hline I h SOD (U/mg) & $0.06 \pm 0.01$ & $0.08 \pm 0.02$ & $0.05 \pm 0.03$ & 0.064 \\
\hline $6 \mathrm{~h} \mathrm{SOD}$ & $0.06 \pm 0.01$ & $0.06 \pm 0.01$ & $0.06 \pm 0.03$ & 0.805 \\
\hline I h CAT (IU/mg) & $0.28 \pm 0.06$ & $0.52 \pm 0.12$ & $0.30 \pm 0.09$ & 0.003 \\
\hline $6 \mathrm{~h} \mathrm{CAT}$ & $0.28 \pm 0.06$ & $0.16 \pm 0.07$ & $0.30 \pm 0.22$ & 0.008 \\
\hline
\end{tabular}

All values are expressed as mean $\pm S D$ or median (IQR), where applicable.

CAT: Catalase; GPx: Glutathione peroxidase; MDA: Malondialdehyde; SOD: Superoxide dismutase. 
sixth $h$ following $\mathrm{TBI}$, respectively. A statistically significant difference was observed in mean serum GPx levels when the trauma and Anakinra groups were compared to the control group $(0.0032 \pm 0.0013 \mathrm{lU} / \mathrm{mg})$ at all time-points $(p=0.003)$. However, there was no statistically significant difference in serum GPx levels between the three time-points of the Anakinra-treated groups $(p=0.513)$ (Table 2).

\section{Tissue and Serum Superoxide Dismutase Analysis}

Mean tissue SOD levels in the trauma groups were $10.05 \pm 0.52$ $\mathrm{U} / \mathrm{mg}, 17.82 \pm 7.11 \mathrm{U} / \mathrm{mg}$, and $19.92 \pm 4.25 \mathrm{nmol} / \mathrm{mg}$ at the first, sixth, and twenty-fourth $h$, respectively. The mean tissue SOD levels in the Anakinra group were $7.63 \pm 1.84 \mathrm{U} / \mathrm{mg}$, $10.14 \pm 4.00 \mathrm{U} / \mathrm{mg}$, and $13.46 \pm 1.46 \mathrm{U} / \mathrm{mg}$ at the first, sixth, and twenty-fourth $\mathrm{h}$ after trauma, respectively. Mean tissue SOD levels of the trauma and Anakinra groups were then compared with those of the control group (I4.5I $\pm 2.74 \mathrm{U} /$ $\mathrm{mg}$ ) and a statistically significant difference was found at all time-points $(p=0.003)$. Mean serum SOD levels in the control group were $0.08 \pm 0.02 \mathrm{U} / \mathrm{mg}$ and $0.08 \pm 0.01 \mathrm{U} / \mathrm{mg}$ at the first and sixth h after sham surgery, respectively. Mean serum SOD levels in the Anakinra group were $0.05 \pm 0.03 \mathrm{U} / \mathrm{mg}$ and
$0.06 \pm 0.03 \mathrm{U} / \mathrm{mg}$ at the first and sixth $\mathrm{h}$ after trauma, respectively. When mean tissue SOD levels in trauma and Anakinra groups were compared with the control group $(0.06 \pm 0.01$ $\mathrm{U} / \mathrm{mg}$ ), no statistically significant differences were found between groups at any of the time-points $(p=0.805)$ (Table 2$)$.

\section{Tissue and Serum Catalase Analysis}

Mean tissue CAT levels in the trauma group were $4.67 \pm 1.69$ $\mathrm{IU} / \mathrm{mg}, 4.06 \pm 0.47 \mathrm{IU} / \mathrm{mg}$, and $7.1 \mathrm{I} \pm \mathrm{I} .85 \mathrm{IU} / \mathrm{mg}$ at the first, sixth, and twenty-fourth $h$, respectively. Mean tissue CAT levels in the Anakinra group were $10.63 \pm 3.55 \mathrm{IU} / \mathrm{mg}, 4.83 \pm \mathrm{I} .07$ $\mathrm{IU} / \mathrm{mg}$, and I.95 $\pm 0.1 \mathrm{I} \mathrm{IU} / \mathrm{mg} \mathrm{I,} \mathrm{6,} \mathrm{and} 24 \mathrm{~h}$ after trauma, respectively. When mean tissue CAT levels in the trauma and Anakinra groups were compared with the control group $(3.48 \pm 0.91 \mathrm{lU} / \mathrm{mg})$, a statistically significant difference was found between groups at all time-points $(p=0.004)$. Mean serum CAT levels in the trauma group were $0.52 \pm 0.12 \mathrm{IU} /$ $\mathrm{mg}$ and $0.16 \pm 0.07 \mathrm{IU} / \mathrm{mg}$ at the first and sixth $\mathrm{h}$, respectively. Mean serum CAT levels in the Anakinra group were $0.30 \pm 0.09$ $\mathrm{IU} / \mathrm{mg}$ and $0.30 \pm 0.26 \mathrm{IU} / \mathrm{mg}$ at the first and sixth $\mathrm{h}$ after trau$\mathrm{ma}$, respectively. No statistically significant difference was observed when CAT levels in the Anakinra group were com-
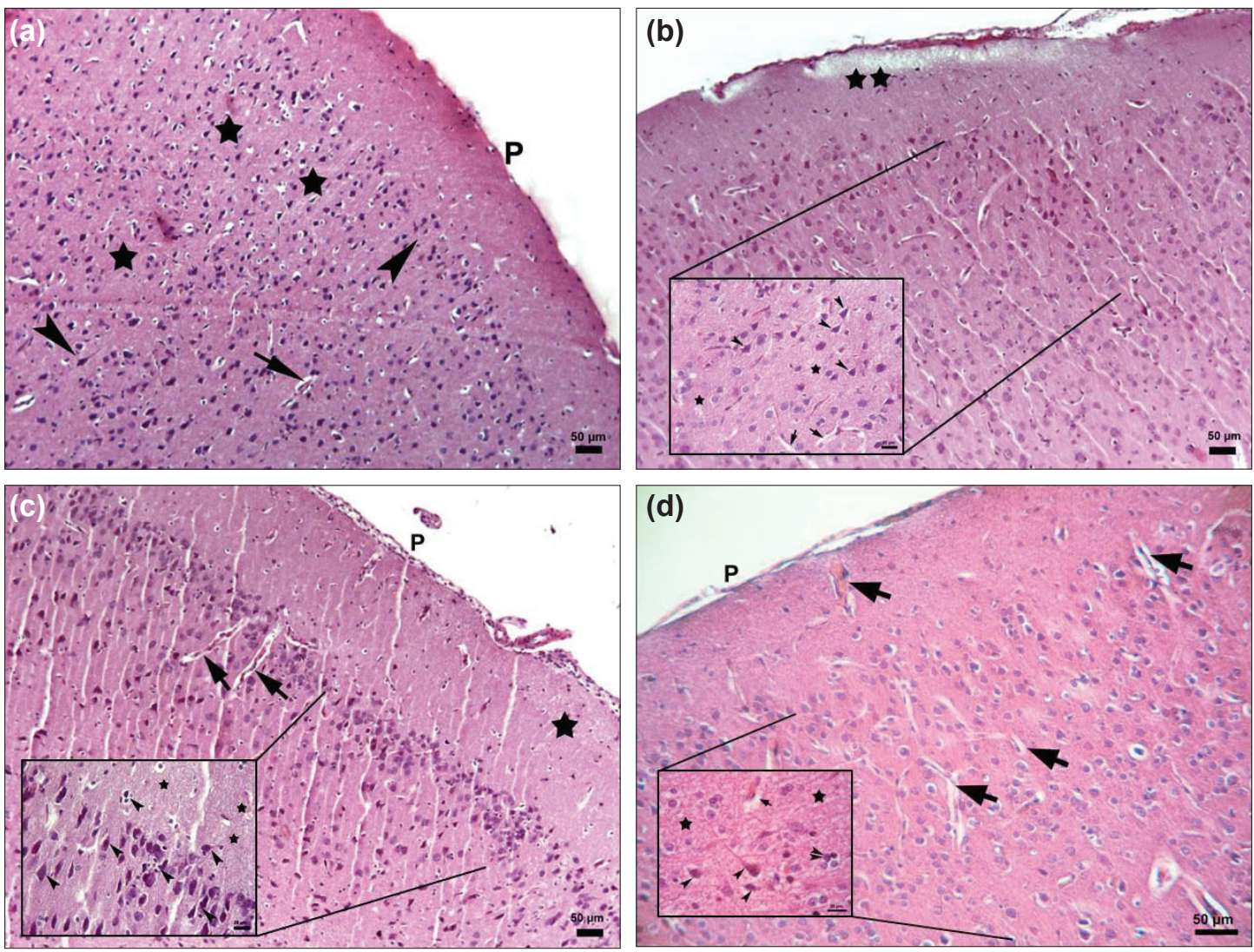

Figure 1. Photomicrograph of the control and trauma groups (a) Control group: The parenchymal features of the cortex morphology appeared normal, P: Piamater, Stars: neurophil, Arrowheads: neurons, Arrows: blood vessels, x10, Bar:50 $\mu \mathrm{m}$; (b-d) Trauma 1,6,24 hours, Stars: edema in neurophil, Arrows: blood vessels with perivascular astrocytic foot process swelling x10, Bar: $50 \mu \mathrm{m}$, inlets: Arrowheads: pyramidal neurons showing cytoplasmic eosinophilia and pyknotic nucleus with perineural satellitosis and cleared areas formed by swollen astrocytic extensions, $x 40$, Bar: 20 $\mu \mathrm{m}$, Hematoxylin-eosin staining. 
Table 3. Mean values of histopathological score distribution among groups after traumatic brain injury

\begin{tabular}{|c|c|c|c|c|c|c|c|}
\hline & Control & $\begin{array}{l}\text { Trauma } \\
\text { I hour }\end{array}$ & $\begin{array}{l}\text { Trauma } \\
6 \text { hour }\end{array}$ & $\begin{array}{l}\text { Trauma } \\
24 \text { hour }\end{array}$ & $\begin{array}{l}\text { Anakinra } \\
\text { I hour }\end{array}$ & $\begin{array}{l}\text { Anakinra } \\
6 \text { hour }\end{array}$ & $\begin{array}{l}\text { Anakinra } \\
24 \text { hour }\end{array}$ \\
\hline \multicolumn{8}{|l|}{ Neuronal degeneration } \\
\hline (cytoplasmic eosinophilia -red neuron-, pyknosis) & 0 & 1.6 & 2.5 & 3 & 2.8 & 2.1 & 2.8 \\
\hline Gliosis/satellitosis & 0 & 1.8 & 2.85 & 3 & 1.45 & 2.3 & 2.45 \\
\hline Spongiosis & 0 & 1.4 & 2.16 & 3 & 2.3 & 2.6 & 2.6 \\
\hline PMNL Infiltration & 0 & 0 & 0 & 0 & 0 & 0 & 0 \\
\hline Vascular congestion & 0 & 1.6 & 2.5 & 3 & 0.3 & 1.3 & 1.3 \\
\hline
\end{tabular}

0-3 (0: absent, I: mild, 2: moderate, 3: common).

pared to serum levels in the control group $(0.28 \pm 0.06 \mathrm{lU} / \mathrm{mg})$ at any of the time-points $(p=0.56)$ (Table 2$)$.

\section{Histopathological Assessment}

All rats of the control group showed no nerve tissue damage in the brain cortex. Neurons and neuroglia cells had normal morphologic features (Fig. Ia). In the first, sixth and twentyfourth h trauma groups, cortical neurons showed cytoplasmic eosinophilia so called eosinophilic neuron and pyknotic nucleus with no discernible nucleolus. Perineural satellitosis accumulating of more than one glia cell around eosinophilic neurons were also observed. The perineural and perivascular spaces were prominent due to the swelling of astrocytic foot processes. In addition, blood vessels showed congestion and stasis. The fibrillary matrix of the cerebral cortex (neurophil) showed spongiosis due to the edema of cellular extensions of the neurons and glia cells (Fig. Ib-d). In the Anakinra applied groups, first, sixth and twenty-fourth $\mathrm{h}$ after trauma also showed same signs of damage of nerve tissue including neurons and neurophil of the brain cortex (Figs. 2a-f). Neuronal degeneration (eosinophilic neurons with pyknotic nucleus) and satellitosis scores of the Anakinra groups were found to be better than trauma groups at the sixth and twenty-fourth h. Moreover, vascular congestion scores were determined to
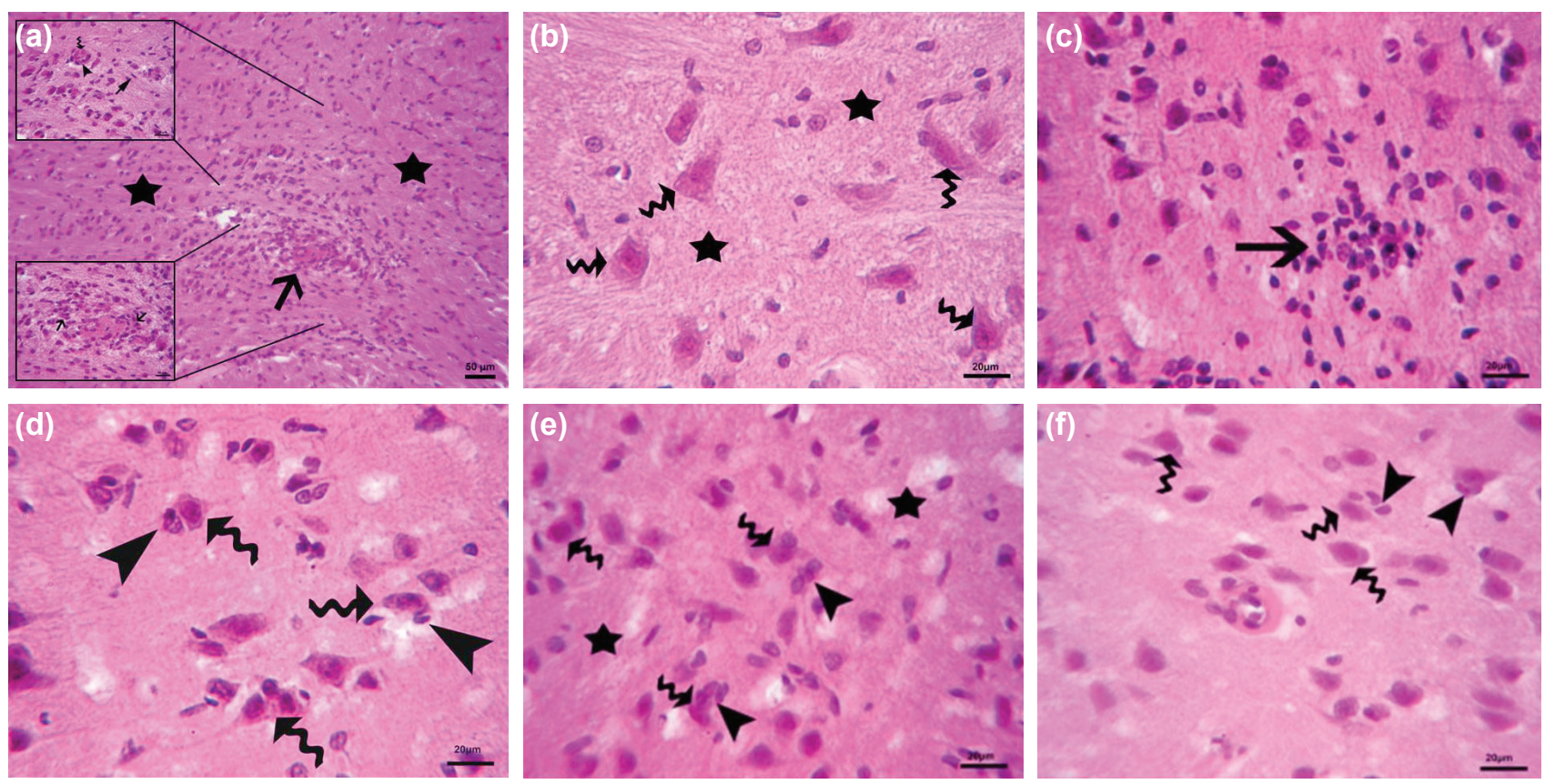

Figure 2. Photomicrograph of brain sections from the Anakinra-treated group $1 \mathrm{~h}$ after trauma (a) Arrow: Gliosis around blood vessels; Star: neurophil, x10, Bar: $50 \mu \mathrm{m}$ inlets: Arrowhead: Satellitosis; Wavy arrow: eosinophilic neuron; Arrow: microglia x40, Bar: $20 \mu \mathrm{m}$ (b) Stars: vacuolization and edema in neurophil; Wavy arrows: neurons with eosinophilic cytoplasm and pyknotic nucleus, $\mathrm{x} 40$, Bar: $20 \mu \mathrm{m}$, Hematoxylin-eosin staining. Photomicrograph of a brain section from the Anakinra-treated group $6 \mathrm{~h}$ after trauma (c) Proliferation of glial cells between injured neurons, x40, Bar: $20 \mu \mathrm{m}$ (d) Arrowheads: perineural satellitosis; Wavy arrows: numerous neurons with eosinophilic cytoplasm and pyknotic nucleus, x40, Bar: $20 \mu \mathrm{m}$, Hematoxylin-eosin staining. Photomicrograph of the Anakinra-treated group $24 \mathrm{~h}$ after trauma, (e, f) Arrowheads: perineural satellitosis; Wavy arrows: neurons with eosinophilic cytoplasm and pyknotic nucleus, $x 40$, Bar: 20 $\mu \mathrm{m}$, Hematoxylin-eosin staining. 
be lower than the trauma groups at all time points and PMNL infiltration was not seen in trauma and Anakinra groups at all time points (Table 3).

\section{DISCUSSION}

Neuronal damage is thought to continue for several days after the initial ischemia expansion occurring within the first 24 $h$ of $\mathrm{TBI}^{\left[{ }^{[13]}\right.}$ The expression of proinflammatory cytokines at the site of injury, including IL-I $\beta$ and TNF- $\alpha$, regulate precise cellular events that occur within the first few hours of TBI and persist in the neural tissue for several days with cytokines also being detectable on microglia, perivascular macrophages, and astrocytes. ${ }^{[14,15]}$ Most important secondary factors leading to further neuronal death are lipid peroxidation, apoptosis, and development of reactive oxygen species. ${ }^{[16-20]}$ In our study, cellular and biochemical changes were observed in order to assess the actual outcome of TBI in relation to short-term histological damage and cytokine expression. Fassbender et al. have analyzed trauma-induced release of IL-I $\beta$ in brain tissue perfusates and reported that IL-I $\beta$ was unexpectedly detected within 60 min of injury. Moreover, extracellularly secreted IL-I $\beta$ protein was found to gradually increase, peaking at day two, and decrease thereafter. Therefore, IL-I $\beta$ release may represent a precondition for the orchestrating role of this mediator in the inflammatory response cascade. ${ }^{[21]}$ In this study, we also demonstrated that serum and tissue levels of IL- I $\beta$ were elevated at the sixth $h$ after TBI. As shown in our results, Anakinra was found to be more effective in reducing tissue levels of IL-I $\beta$ in the first $h$ after trauma. This finding is not surprising since the release of IL- $\mathrm{I} \beta$ in brain tissue occurs within less than one $h$ of trauma. Rothwell et al. have shown that neuronal inflammation, inducing pro-cytokine IL-I $\beta$, plays a key role in this process involving glial cells as well as invading immune cells. Moreover, induced cytokines have been suggested to indicate the extent of central nervous system injury. ${ }^{[14,22]}$ In the present study, morphological features relevant with neuronal injury and higher histopathological scores following brain trauma in rats were demonstrated. In contrast, administration of Anakinra led to an improvement of nerve tissue and cell morphology after TBI through a reduction in oxidative stress. Furthermore, this amelioration was revealed to be associated with decreased tissue and serum levels of IL-I $\beta$. On the contrary, no significant reduction in MDA was observed, indicating a lack of lipid peroxidation inhibition in brain sections and serum levels obtained from Anakinratreated rats. This observation is in disagreement with a study conducted by Marini et al. demonstrating that inhibition of lipid peroxidation has reduced IL-I $\beta$ expression and protected neuronal tissue from damage. ${ }^{[20]}$ Finally, the evaluation with light microscopy showed that the histopathological damage scores of neuronal degeneration, satellitosis, vascular congestion and spongiosis were reduced in rats treated with Anakinra at the twenty-fourth $h$ after TBI. The findings of the current study suggested that IL-I $\beta$ played a detrimental role in the development and severity of post-traumatic injury and that this damaging effect could be attenuated by blocking this cytokine's signaling pathway.

Treatment with Anakinra inhibits IL-I $\beta$ and protects the brain tissue and neuronal cells from damage in TBI. However, a few of the possible mechanisms by which Anakinra attenuates neurological injury were demonstrated in this study and a better understanding of the mechanisms of Anakinra might lead to future clinical strategies aimed at treating TBI.

\section{Conflict of interest: None declared.}

\section{REFERENCES}

1. Yakovlev AG, Faden AI. Mechanisms of neural cell death: implications for development of neuroprotective treatment strategies. NeuroRx 2004;1:5-16. CrossRef

2. Bartholdi D, Schwab ME. Methylprednisolone inhibits early inflammatory processes but not ischemic cell death after experimental spinal cord lesion in the rat. Brain Res 1995;672:177-86. CrossRef

3. Hayashi M, Ueyama T, Nemoto K, Tamaki T, Senba E. Sequential mRNA expression for immediate early genes, cytokines, and neurotrophins in spinal cord injury. J Neurotrauma 2000;17:203-18. CrossRef

4. Courcoul A, Vignot E, Chapurlat R. Successful treatment of ErdheimChester disease by interleukin-1 receptor antagonist protein. Joint Bone Spine 2014;81:175-7. CrossRef

5. Nandi P, Kingsley GH, Scott DL. Disease-modifying antirheumatic drugs other than methotrexate in rheumatoid arthritis and seronegative arthritis. Curr Opin Rheumatol 2008;20:251-6. CrossRef

6. Marmarou A, Foda MA, van den Brink W, Campbell J, Kita H, Demetriadou K. A new model of diffuse brain injury in rats. Part I: Pathophysiology and biomechanics. J Neurosurg 1994;80:291-300. CrossRef

7. Ucar T, Tanriover G, Gurer I, Onal MZ, Kazan S. Modified experimental mild traumatic brain injury model. J Trauma 2006;60:558-65. CrossRef

8. Paglia DE, Valentine WN. Studies on the quantitative and qualitative characterization of erythrocyte glutathione peroxidase. J Lab Clin Med 1967;70:158-69.

9. Tator $\mathrm{CH}$, Fehlings MG. Review of the secondary injury theory of acute spinal cord trauma with emphasis on vascular mechanisms. J Neurosurg 1991;75:15-26. CrossRef

10. Sun Y, Oberley LW, Li Y. A simple method for clinical assay of superoxide dismutase. Clin Chem 1988;34:497-500.

11. Aebi H, Wyss SR, Scherz B, Skvaril F. Heterogeneity of erythrocyte catalase II. Isolation and characterization of normal and variant erythrocyte catalase and their subunits. Eur J Biochem 1974;48:137-45. CrossRef

12. Mena H, Cadavid D, Rushing EJ. Human cerebral infarct: a proposed histopathologic classification based on 137 cases. Acta Neuropathol 2004;108:524-30. CrossRef

13. Yilmaz ER, Kertmen H, Gürer B, Kanat MA, Arikok AT, Ergüder BI, et al. The protective effect of 2-mercaptoethane sulfonate (MESNA) against traumatic brain injury in rats. Acta Neurochir (Wien) 2013;155:141-9.

14. Song C, Zhang Y, Dong Y. Acute and subacute IL-1 $\beta$ administrations differentially modulate neuroimmune and neurotrophic systems: possible implications for neuroprotection and neurodegeneration. J Neuroinflammation 2013;10:59. CrossRef

15. Cheong CU, Chang CP, Chao CM, Cheng BC, Yang CZ, Chio CC. Etanercept attenuates traumatic brain injury in rats by reducing brain TNF- $\alpha$ contents and by stimulating newly formed neurogenesis. Mediators Inflamm 2013;2013:620837. CrossRef 
16. Ates O, Cayli S, Altinoz E, Gurses I, Yucel N, Sener M, et al. Neuroprotection by resveratrol against traumatic brain injury in rats. Mol Cell Biochem 2007;294:137-44. CrossRef

17. Awasthi D, Church DF, Torbati D, Carey ME, Pryor WA. Oxidative stress following traumatic brain injury in rats. Surg Neurol 1997;47:57582. CrossRef

18. Nishio S, Yunoki M, Noguchi Y, Kawauchi M, Asari S, Ohmoto T. Detection of lipid peroxidation and hydroxyl radicals in brain contusion of rats. Acta Neurochir Suppl 1997;70:84-6.

19. Pineda JA, Wang KK, Hayes RL. Biomarkers of proteolytic damage fol- lowing traumatic brain injury. Brain Pathol 2004;14:202-9. CrossRef

20. Marini H, Altavilla D, Bellomo M, Adamo EB, Marini R, Laureanti F, et al. Modulation of IL-1 beta gene expression by lipid peroxidation inhibition after kainic acid-induced rat brain injury. Exp Neurol 2004;188:17886. CrossRef

21. Fassbender K, Schneider S, Bertsch T, Schlueter D, Fatar M, Ragoschke A, et al. Temporal profile of release of interleukin-1beta in neurotrauma. Neurosci Lett 2000;284:135-8. CrossRef

22. Rothwell N. Interleukin-1 and neuronal injury: mechanisms, modification, and therapeutic potential. Brain Behav Immun 2003;17:152-7. CrossRef

\section{DENEYSEL ÇALIŞMA - ÖZET}

\section{İnterlökin 1-beta inhibitörü Anakinra'nın sıçanlarda travmatik beyin hasarına karşı terapötik etkinliğinin değerlendirmesi}

Dr. Aşkın Esen Hastürk, ${ }^{1}$ Dr. Erdal Reşit Yılmaz, ${ }^{2}$ Dr. Erhan Türkoğlu, ${ }^{2}$ Dr. Hayri Kertmen, ${ }^{2}$
Dr. Bahriye Horasanlı, ${ }^{2}$ Uzm. Bio. Nazlı Hayırlı, ${ }^{4}$ Dr. Imge Berrin Ergüder, ${ }^{5}$ Dr. Oya Evirgen ${ }^{4}$

${ }^{1}$ Onkoloji Eğitim ve Araştırma Hastanesi, Beyin ve Sinir Cerrahisi Bölümü, Ankara;

${ }^{2}$ Dışkapı Yıldırım Beyazıt Eğitim ve Araştırma Hastanesi, Beyin ve Sinir Cerrahisi Bölümü, Ankara;

${ }^{3}$ Başkent Üniversitesi Tıp Fakültesi, Nöroloji Anabilim Dalı, Ankara;

${ }^{4}$ Ankara Üniversitesi Tıp Fakültesi, Histoloji ve Embriyoloji Anabilim Dalı, Ankara;

${ }^{5}$ Ankara Üniversitesi Tıp Fakültesi, Biyokimya Anabilim Dalı, Ankara

AMAÇ: Bu çalışmanın amacı, deneysel travmatik beyin hasarı $(\mathrm{TBH})$ modelinde interlökin I beta (IL-I $\beta$ ) inhibitörü Anakinra'nın tedavi edici etkinliğinin değerlendirilmesidir.

GEREÇ VE YÖNTEM: Elli dört Wistar albino sıçana anestezi uygulaması sonrası kafatası üzerine konan bir metal disk üzerine 2 metreden $450 \mathrm{~g}$ ağılık düşürülerek deneysel kapalı kafa travması oluşturuldu. Hayvanlar üç ana gruba ayrıldı: Kontrol $(n=18)$, TBH + salin ( $n=\mid 8$; zaman başına altı hayvan) numuneler bir, altı ve 24 saat sonra alındı ve TBH + Anakinra ( $n=18$; zaman başına altı hayvan) numuneler bir, altı ve 24 saat sonra alındı. ILI $\beta$, malondialdehit, glutatyon peroksidaz, süperoksit dismutaz ve katalaz düzeylerinin analizi için beyin dokusu ve kan örnekleri alındı. Doku kesitleri histopatolojik olarak ışık mikroskobunda değerlendirildi.

BULGULAR: Travma sonrası, doku ve serum IL-I $\beta$ düzeyleri önemli ölçüde artmıştı ve bu düzeyler Anakinra verilmesinden sonra azaldı. TBH takiben glutatyon peroksidaz, süperoksit dismutaz ve katalaz aktivitesi azalmış ve Anakinra uygulanması bu antioksidan enzimlerin aktivitesini artırmada etkili olmuştur. Histopatolojik analiz Anakinra'nın beyin dokusu ve sinir hücrelerini travmadan koruyabileğini doğrulamıştır

TARTIŞMA: Anakinra'nın TBH ile ortaya çıkan enflamasyon ve doku hasarı gelişimini azalttığını göstermektedir.

Anahtar sözcükler: Anakinra; antioksidan; interlökin-I; nöroproteksiyon; travmatik beyin hasarı.

Ulus Travma Acil Cerrahi Derg 2015;2I (I):I-8 doi: 10.5505/tjtes.2015.57894 